\title{
Okoubaka Aubrevillei (Pelleg \& Norman): A Synthesis of Existing Knowledge for Research and Conservation in West and Central Africa
}

\author{
Temitope Israel Borokini ${ }^{1,2}$ \\ ${ }^{1}$ Plant Genetic Resources Unit, National Center for Genetic Resources and Biotechnology \\ (NACGRAB), Ibadan, Nigeria \\ ${ }^{2}$ Program in Ecology, Evolution and Conservation Biology, College of Science, University of \\ Nevada Reno, Reno NV 89557-0314. \\ E-mail: tbisrael@gmail.com
}

Received: October 4, 2014 Accepted: October 21, 2014

doi:10.5296/jbls.v6i1.6399 URL: http://dx.doi.org/10.5296/jbls.v6i1.6399

\begin{abstract}
Okoubaka aubrevillei is the largest parasitic plant known to man. It is a tropical tree species distributed within West and Central Africa. Concerns were drawn to the tree because of its rarity, disjunct distribution in all its native range, paucity of published scientific information and its hemi-parasitic potentials. This article gathered and synthesized all existing scientific information on the tree to provide a solid foundation for further research on the tree. This article provided detailed information on its name etymology, taxonomic history, and geographical distribution including new locations for the tree, ecological significance and behaviour within its range, supported with an updated map illustrating its distribution within West and Central Africa. The possible causes of its rarity in its range were identified and its hemi-parasitic behaviour was hypothesized. In addition, ethnobotanical uses of the tree, symbolism and dendrolatry, and its significance in modern medicine were extensively discussed. The paper concluded with highlights on prospects for immediate conservation, management and research focus areas for the tree species.
\end{abstract}

Keywords: Okoubaka aubrevillei, West and Central Africa, Conservation, Hemi-parasitism, Rarity.

\section{Introduction}

Okoubaka aubrevillei is an indigenous tree species from the tropical rainforests of West and Central Africa (Tailfer, 1989), reaching $40 \mathrm{~m}$ in height (Hawthorne, 1995). The generic name 
comes from oku baka, in Anyin language (Côte d'Ivoire) meaning "a tree with allelopathic properties", or "a tree that causes the death of surrounding vegetation" (Hallé, 1987), or simply "death tree" (Lowe, 2012). This tree is of significant interest because of symbolic veneration attached to it by indigenous communities in all its native range, its numerous medicinal potentials and conservation status. The tree is perhaps one of the most controversial plants in Africa in terms of taxonomy and ethnobotanical information.

The author's attention was drawn to the tree as because of its rarity in its native range, and relative neglect in terms of research and publications. A search for publications on the tree on ISI Web of Science and JSTOR journal databases gave only 18 and 5 publications respectively, with only 4 publications with research focused directly on the tree. This paper gave a comprehensive compendium on existing knowledge on the tree from the few published research papers and from author's personal experiences and reconnaissance surveys. In this way, knowledge gaps are identified and baseline information on the tree are registered, in order to stimulate further goal-oriented studies on the tree.

\section{Morphological Features}

Okoubaka aubrevillei is a tropophyte which grows to a height to up to 40 metres; with trunk as wide as $3 \mathrm{~m}$. The tree has huge bushy crown, cylindrical and straight bole, coarse bark surface which is usually reddish brown. The horizontal branches divide to form slightly grooved and densely hairy branchlets (Burkill, 2000). The tree is monoecious, deciduous, and the tree development fits in Mangenot architectural model (Hallé and Oldeman, 1970; Hallé et al., 1978). This model describes trees where "the trunk is formed by superposition of renewal shoots from lateral buds, the new shoot is initially orthotropic but later becomes plagiotropic, while the phyllotaxy is spiral in the orthotropic parts and distichous in the plagiotropic parts" (Hallé and Oldeman, 1970; Ladipo et al., 2008).

The following is a synthesis of leaf descriptions given by different authors: "The leaf blade is ovate to oblong, simple and entire, $7.5-15 \mathrm{~cm}$ long and $3.5-6 \mathrm{~cm}$ wide. Leaf arrangement is alternate to almost opposite (Fig. 1), stipules are absent, petiole is 2-ribbed and 3-15 mm long. The leaf base is rounded to slightly cordate while the apex is acuminate. The leaf is dark green, with 3-5 pairs of lateral veins and densely hairy when young. The axes show clear articulation. The pubescence of the leaves and axes consists of long, pointed, simple hairs, existing in tufts or bundles of 2-3 hairs, the hairs are always normal" (Stauffer, 1957; Voorhoeve, 1965; Ladipo et al., 2008).

The tree's small, greenish flowers are arranged on spines of around $15 \mathrm{~cm}$ in length on older branches. Inflorescences are 20-40 cm long and 6-10 cm wide. The inflorescences occur axillary on older branches, and shortly pedicellate flowers show a conical receptacle, into which the unseptate ovary is encompassed (Stauffer, 1957). Furthermore, unisexual flowers are in multiples of 5, sessile and greenish. Male flowers have triangular petals, about $2.5 \mathrm{~mm}$ long and $2.5 \mathrm{~mm}$ wide, short-hairy, with stamens about $0.5 \mathrm{~mm}$ long, disk cup-shaped, lobed, ovary with abortive ovules, style c. $1 \mathrm{~mm}$ long, stigma 4-pointed; female flowers slightly larger than male flowers, stamens sterile, disk cup-shaped, prominently lobed, hairy on upper margin, ovary superior, 4-celled, style c. 1 mm long, stigma 4-lobed (Ladipo et al., 2008). 


\section{MInstitute Macrothink $_{\text {Int }}$}

Journal of Biology and Life Science ISSN 2157-6076 2015, Vol. 6, No. 1

The flowers turn into hard, yellow-coloured fruits (Fig. 2) which are ellipsoid drupes, containing a single large seed (Wagner et al., 1985; Abbiw, 1990). The fruits are glabrous, $15-16 \mathrm{~cm}$ long and 9-10 cm wide, weakly ribbed longitudinally; the exocarp is smooth, shiny, apple green coloured and then to yellow at full maturity; mesocarp is golden-yellow, of $1.5-2$ cm thick; endocarp of $5 \mathrm{~mm}$ thickness (Hallé, 1987).

The seed is ellipsoid, $7 \mathrm{~cm}$ long and $4.5 \mathrm{~cm}$ wide, with white endosperm, and longitudinally ridged (Burkill, 2000). The weight of the fresh seed was reported to be $100 \mathrm{~g}$ (Kyereh et al., 1999) or $101 \mathrm{~g}$ (Veenendaal et al., 1996a), compared to Balanites wilsoniana (50 g), Mammea africana (38 g) and Tieghemella heckelii (19 g), while Nagaveni and Anantha Padmanabha (1986) reported the dry seed mass to be $43 \mathrm{~g}$, the largest reported for a hemiparasite. The seeds undergo cryptocotylar hypogeal germination (de la Mensbruge, 1966).

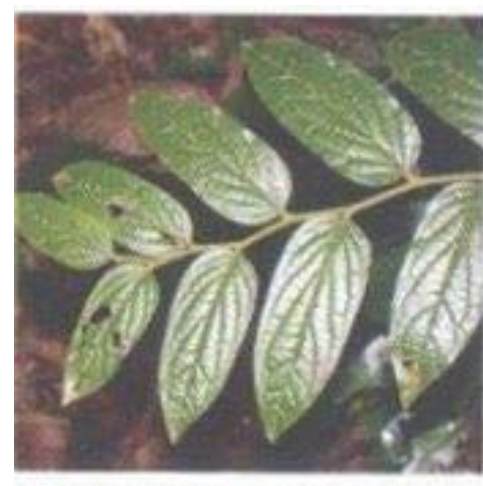

p. 324 Okoubaka aubrevillei

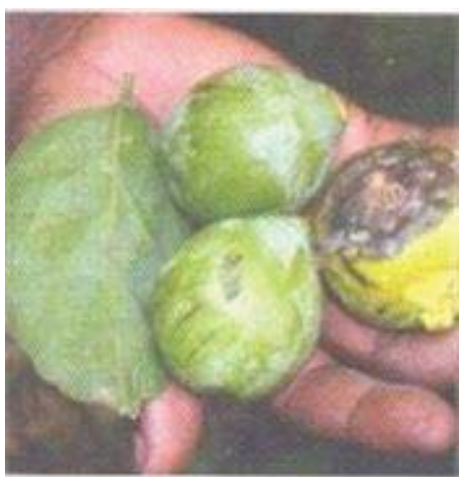

Okoubaka aubrevillei

Figure 1. Leaves of $O$. aubrevillei

Figure 2. Fruits of $O$. aubrevillei

\section{Source: Flora and Fauna of Liberia}

The wood of $O$. aubrevillei is straight-grained, heavy and hard, with a basic density of 0.68 $\mathrm{g} / \mathrm{cm}^{3}$ (Bluskova et al., 1995). Anatomical descriptions of xylem of this species have been reported by Normand (1944, 1950, 1972), Lebacq and Dechamps (1964, 1967), and Normand and Paquis (1977); however, only Normand (1972) noted the occurrence of disjunctive parenchyma in the wood. Details of sections of the seed (nuts), pollen, fruit and flower have been given by Hallé (1987).

\section{Taxonomic history: Octoknemaceae, Santalaceae or Cervantesiaceae?}

Having made a first collection in Ivory Coast (Côte d'Ivoire) in 1936, the species was first described, in French, in 1937 and named Octoknema okoubaka Aubrév. \& Pellegr by Aubréville and Pellegrin (1937), based on the description of the placenta of Octoknema klaineana by Pierre (1897). The genus Octoknema originally comprised 7 species found and described in different parts of West, Central and East Africa between 1897 and 1932 (Gosline and Malecot, 2011). As a result, this species was placed in the monogeneric family Octoknemaceae (often wrongly spelled Octoknemataceae) in the order Santalales (Gosline and Malecot, 2011). However, Norman (1944) discovered the anatomical study of wood did not agree with Octoknema and also, another important discovery, that the species is closely 
connected to Santalaceae (Norman, 1950). Pellegrin and Norman (1946) proposed a new genus and a validated new name, Okoubaka aubrevillei (Pelleg \& Norman). Without considering placentation, the new genus remained within Octoknemaceae (Hallé, 1987). In December 1947, a new variety, glabrescentifolia, was discovered in Yangambi, Democratic Republic of Congo (formerly Zaire) by Leonard (1947) with similar hemi-parasitic traits. This new variety was formally named Okoubaka aubrevillei var glabrescentifolia in Octoknemaceae and listed in the Flora of Belgian Congo (Hallé, 1987). However, Stauffer (1957), having revised the floral characters of Okoubaka aubrevillei, confirmed that it is indeed Santalaceae, and its affinity with Scleropyrum, an Indomalaysian genus with several species. Subsequently, the monogeneric Octoknemaceae family was dissolved, as the only genus, Octoknema was moved to Olaceae family. However, certain publications wrongly placed Okoubaka aubrevillei under Olaceae family under the Octoknema genus (Gosline and Malecot, 2011). A second species, Okoubaka michelsonii, was collected by A. Michelson in 1948 and 1949, and described by Leonard and Troupin (1950).

In spite of this changes in its taxonomic classification, 30 years after, the error of placing it under Octoknemaceae family is still persistent in Floras and herbaria (Hallé, 1987). Such examples include Lucas (1968)'s Flora of East Africa, Aubrevillei (1959)'s Forest Flora of Ivory Coast, Keay (1958)'s revision of Hutchinson and Dalziel's Flora of West Tropical Africa, as well as Keay (1989)'s Trees of Nigeria, among others. Even till date, some authors still place it under Octoknemaceae family in recent publications. However, Burkill (2000)'s The Useful Plants of West Tropical Africa (UPTWA) published the tree under Santalaceae; while Mangenot and Mangenot (1962) reported the chromosome number for O. aubrevillei to be $2 \mathrm{n}=$ 72. Since a second variety was discovered, it is appropriate to call the first one, Okoubaka aubrevillei var aubrevillei.

However, recent molecular phylogenetic studies (Nickrent and Malécot, 2001; Malécot 2002) showed Okoubaka to be member of a clade of paraphyletic Santalaceae; and Dar \& Nickrent (2008) and Nickrent et al. (2010) placed it in a new family, Cervantesiaceae Nickrent \& Der still within the order Santalales. Currently, Okoubaka consists of two species, and a variety; $O$. aubrevillei being the primary West African species, and O. michelsonii endemic to Democratic Republic of Congo (DRC). O. michelsonii is distinguished from O. aubrevillei by its glabrous branchlets and disk, shorter inflorescence and smaller fruits (Leonard and Troupin, 1950; Ladipo et al., 2008). Leonard and Troupin (1950) developed a key to describe the 3 members of the Genus Okoubaka and distinguished it from Genus Octoknema, where it was previously placed:

A. Parts young (branchlets, petioles, inflorescences) glazes of spangled hairs; not articulated petioles; staminodes deprived of anthers; 3-(4)-locular ovary almost until the top, becoming unilocular by tearing of the partitions; $1.5-3 \mathrm{~cm}$ length drupes; endocarp emitting towards the interior $6-10$ thin blades Octoknema.

B. Young parts (branchlets, petioles, inflorescences) glabrous or glazes of hairs simple, bifurcate or sometimes stellate; articulated petioles; staminodes with anthers; unilocular ovary; 4-16 cm length drupes; endocarp not emitting thin blades towards the 
interior. .Okoubaka

The genus Okoubaka Pellegr. \& Norman currently includes 2 species and 1 variety:

A. Pubescent branchlets and disks; panicles borne on old wood, of 18-40 cm length; drupes sessile, with 3.5-5 $\mathrm{mm}$ thick endocarp:

I. Blade densely pubescent, glabrous; receptacle and external face of the covered sepals with many stellate hairs; $9 \mathrm{~cm}$ long drupes. 1. O. aubrevillei var aubrevillei

II. Blade glabrescent to glabrous even in a very young state; receptacle and external face of the sepals covered with scattered, simple, bifurcate or stellate hairs; $15-16 \mathrm{~cm}$ long drupes. 2. O. aubrevillei var. glabrescentifolia

B. Glabrous branchlets and disks; racemes spiciform, axillary (or borne on old wood?), of 1-3 $\mathrm{cm}$ length; drupes pedicellate, $+4 \mathrm{~cm}$ long, with $0.3 \mathrm{~mm}$ thick endocarp. 3. O. michelsonii

Herbarium records available online for the tree are found in Forestry Research Institute of Nigeria (FRIN), Ibadan, Nigeria; Museum National d'Histoire Naturelle, Côte d'Ivoire; University of Ghana herbarium, Ghana; Université de Kinshasa and Institut National pour l'Etude et la Recherche Agronomiqué Centre de Recherches Herbier, both in Democratic Republic of Congo. In addition, non-African herbaria with Okoubaka records include Royal Botanic Garden, Kew; Nationaal Herbarium Nederland, National Botanic Garden of Belgium, Wageningen University (WUR) herbarium, The Netherlands and Missouri Botanic Garden, USA, with their herbarium collections coming from Ghana, Côte d'Ivoire, Sierra Leone, Liberia and Democratic Republic of Congo.

\section{Literatures}

Scientific knowledge for this tree species are scanty (Cunningham, 1993) and relatively little is known about the two species and their sister variety. Veenendaal et al. (1996a) reported hemi-parasitism in $O$. aubreville $i$ which they noted from 6 months old seedlings. The victims of the tree's hemi-parasitism were Entandrophragma angolense (Wei.) DC, Pericopsis elata (Harms) Van Meeuwen, Pterygota macrocarpa K. Schum., and Tieghemella heckelii Pierre ex Chev; but $P$. macrocarpa, and the nitrogen fixing legume, $P$. elata were reported to be the most infected. Furthermore, Kitin et al. (2009) worked and described a poorly known type of xylem parenchyma with disjunctive walls in the tree. Recently, van Andel et al. (2014) reported the first ever species distribution modelling for the tree in West Africa. These are in addition to a few studies reported on its pharmacological properties.

\section{Geographical Distribution}

The tree is distributed from Sierra Leone east to Cameroon and DRC (Ladipo et al., 2008); however, the largest population of the tree was found in the Upper Guinea region comprising Sierra Leone, Liberia, Ghana and Côte d'Ivoire (Poorter et al., 2004). Generally, the tree is reported to be restricted to closed cover evergreen forest (Burkill 1985), but also reported on rocky hills (Dovi, 2013) or slopes, usually solitary in most locations, but there are reports from 


\section{Macrothink}

Journal of Biology and Life Science ISSN 2157-6076 2015, Vol. 6, No. 1

Côte d'Ivoire and Ghana that it is found in pure stands (Ladipo et al., 2008). In addition, the tree is also found to grow in open places in the forest. Akotto et al. (2014) reported the tree in high slopes and midslopes in Côte d'Ivoire.

The tree was first reported from Côte d'Ivoire (Ivory Coast) by Aubréville and Pellegrin (1937), later by Mensbruge (1966) and again by Hallé and Oldeman (1970), while other occurrences were reported from other parts of West Africa. Lemee (1959) and Letouzey (1960) cited in Hallé (1987) discovered the tree in Cameroon; Irvine (1961) reported it in Ghana, and Villiers (1973) in Gabon. Hallé (1987) cited Bold (1963) recording the tree in Niger Republic but no scientific data supports this, as Maercklein (2008)'s biodiversity report for Niger Republic reported only tree species that are generally adapted to Savanna ecoregions. Therefore, the occurrence of $O$. aubrevillei in Niger Republic is highly unlikely. Furthermore, the tree was reported from Sapoba Forest Reserve (FR), which were probably the ones planted by J.D Kennedy in 1930 (Hardie 1963).

Sapoba FR was the only recorded location for the tree in Nigeria as collected and filed in 1975 at the Federal Herbarium Ibadan (FHI) of FRIN, Ibadan and confirmed recently in personal communications with Mr. B.O Daramola. New locations for the tree have been reported in recent times. Ihenyen et al. $(2009,2010,2011)$ reported the tree from Ehor FR, Edo State, Nigeria, with a reported density/hectare of 0.127 . However, Ihenyen et al. (2011) reported not sighting the tree in Sapoba FR, as well as in Okomu National Park and Ozalla-Ora-Iulleha FR. Borokini and Clement (2012) reported its barks being sold in Bode Ibadan herbal market, which was traced to Onitsha, Anambra State. Furthermore, a stand was reported in Iwara town, Osun state, which is being worshipped as a sacred tree (god) till date (Ladipo et al., 2008). Ishikuemen and Iduozee (2008) reported coppices of this tree in Urhonigbe FR with Myrianthus arborea stands beside it (Fig. 3). Ita and Offiong (2013) reported the tree and its use in Cross River State. In the author's personal trip, the tree was encountered in Boki, Cross River but the traditional rulers refused access to the tree. Therefore, it appears that the tree is confirmed from Edo, Cross River and Osun States and probably Anambra State.
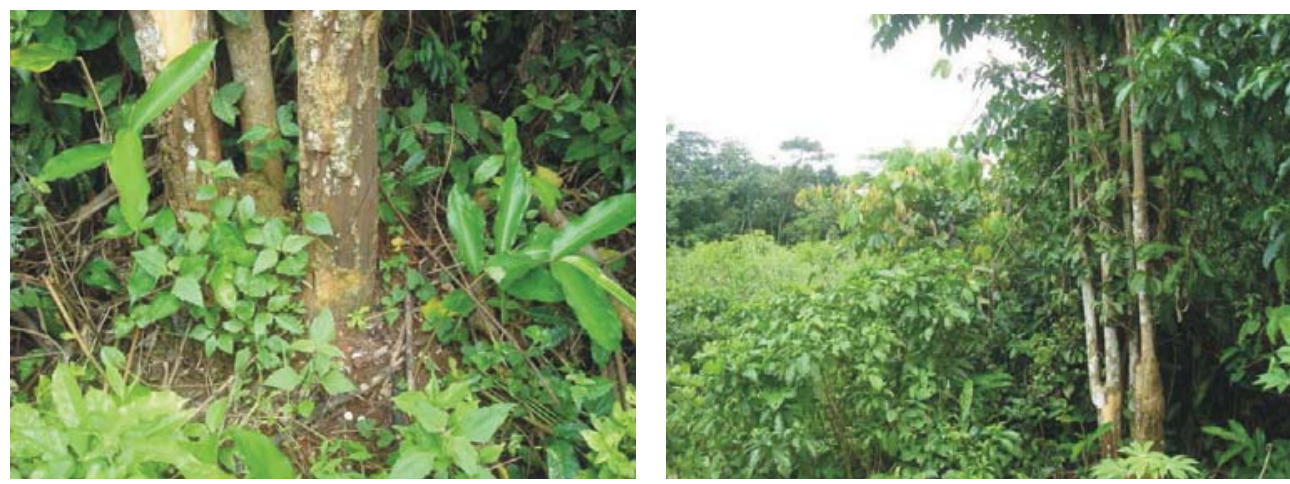


\section{Macrothink}
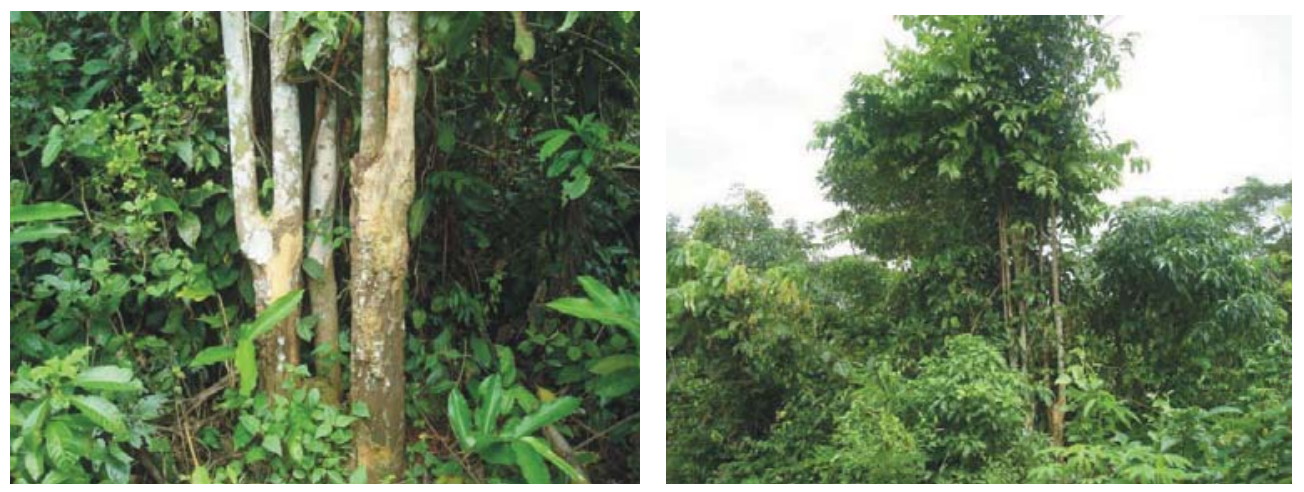

Figure 3. Coppiced Saplings of Okoubaka aubrevillei (Left of O. aubrevillei is Myrianthus arborea) Source: Isikhuemen and Iduozee (2008).

JSTOR filed the tree as reported by Leonard (1947) from forest reservations in Yapo, Agboville and Yakassé; Mampong Scarp Vigne, Krakaw, on N.E. corner of Kade Bepo F.R., Kwahu and Mpraeso, in Côte d'Ivoire. However, the tree has been further reported from Taï Forests National Park (Rompaey, 1993) and forests of Sanaimbo (Kassi et al., 2012). Akotto et al. (2014) reported it in their study sites in Akye country, southeastern Côte d'Ivoire. A few specimens of $O$. aubrevillei were reported from Dodo Hills and Gola Forest Reserves in Sierra Leone (Savill and Fox, 1967), while it was also listed in Bossou, Republic of Guinea, with leaves reportedly consumed by chimpanzees (Hockings, 2007). The tree was also listed in Deng Deng Forest, Cameroon (Ariz. Univ. Office of Arid Land Studies, 1981). Recent additional sightings have been recorded in Tiwai Islands (Sierra Leone), around Ndian community and Réserve de Faune de Pangaret Djérem (Cameroon).

The tree was reported in Atewa Range Forest reserve (Asiakwa South) in Ghana by Hawthorne (1998), and also confirmed by Okyeman Environment Foundation (2003). Myren (2011) reported the tree in sacred forests/shrines in Akoase, Southern Ghana; Houghton (2003) mentioned another stand from another study site in southern Ghana, while recent GBIF (2010) records indicate its presence in Boin Tano and Tano-Nimire Forest Reserve. Marshall (2011) reported two stands in a ridge top forest in Karlowleh and Pennoken communities, Liberia, however in recent communications with Liberian Forestry officers, new locations were noted in Grand Gedeh-Pennoken, River Gee - Proposed Grebo National Park, River Cess and Gbarpolu Gola Forest. Marshall (2011) further reported the limited distribution of the tree in the scattered Upper Guinea hills in Liberia. The genus has its center of diversity in DRC, as both varieties aubrevillei and glabrescentifolia of Okoubaka aubrevillei as well as Okoubaka michelsonii have been reported in the country. Louis (1948) reported O. aubrevillei from the Central Forests at Yangambi, DRC, while GBIF and African Plant Database records indicate herbarium collections in Kwango, Yaboseo, Lilanda and Bena Longo communities.

The tree was also reported from one of the quadrant points in a study in Dzanga Sangha Protected Area complex of Central African Republic (Balinga et al. 2006), its ethnobotanical use was reported from Burkina Faso, a strong indication of its distribution in the country (Kone et al., 2008). There is no specific herbarium record or sighting of $O$. aubrevillei in Benin Republic but van Andel et al. (2014), using Maximum Entropy (MaxEnt) species distribution 
modelling (SDM) tool and GIS-based mapping, estimated suitable habitat for the tree in the country; while Codjia and Boer (2014) wrote on attempts to use it in agroforestry within oil palm plantations in Benin Republic. Central African Republic, Burkina Faso and Benin Republic are new locations not previously reported in UPTWA, FWTA and other global or continental plant databases. Furthermore, the tree's range extended to Liberia and Burkill (1985) reported a ban by Liberian Government on its bark sale. The Flora and Fauna of Liberia website listed it as one of the country's native species, with a note that it is endemic to West Africa. In an Environmental Impact Assessment (EIA) studies conducted in Nimba Western Area, Liberia, one stand was found far up Yuelliton in Bentor, another stand in Tokadeh forest, Makinto, and another one, called Zo tree in Zolowee, and other stands in Vanyampa and Sehyigeh communities (URS, 2013).

Tropicos online Plant database of the Missouri Botanical Garden listed two specimens for the tree from Nzérékoré, Guinea Republic and Haut, DRC (Tropicos, 2014). Furthermore, a list of occurrence of the tree on Global Biodiversity Information Facility (GBIF, 2010) produced results of registered 86 locations many of which have incomplete information, while some of the reported coordinates for the tree are inaccurate when plotted on ArcGIS map version 10.2 (ESRI, 2013). Furthermore, many of the herbaria collections were made in the mid-20th century and personal communication with some experts indicate that the stands were no longer found in some of these reported locations of herbarium specimens.

All the reported distributions of the tree are based on sightings and available herbarium records, portraying a disjunct distribution within the subcontinent (Poorter et al., 2004). However, herbarium records from Nigeria were not included in the GBIF database and CJB African Plant database records available for this plant; in spite of the fact that the tree has been reported from Nigeria. Therefore, it is very likely that the "gap in distribution" between Ghana and Nigeria would disappear if the tree is sighted and reported from Togo, while it is suspected that the tree might also be in Equatorial Guinea mainland and Congo Republic.

The presence of local names for a plant indicate the nativity of that plant in the local area. Local names for the tree include igi-nla (Yoruba), akoelisi, akuobisi and okoubisi (Bini names, meaning big tree), Etokukim (Cross River State), Nigeria; odii/ode (Twi language of Akan and Asante peoples), duyin (Fante language of Akan people), Ghana; oku baka (Anyi), Côte d'Ivoire; yai yili or Yein-yelee (Mano, meaning a lonely tree), Kahn tu/Sarlyea tu (Krahn language), Liberia; youa (Kono), yuwe (Mende), Sierra Leone (Hutchinson and Dalziel, 1958; Burkill, 1985; Marshall and Hawthorne, 2012a; Ita and Offiong, 2013; URS, 2013).

Scientific information are lacking on Okoubaka aubrevillei var. glabrescentifolia J.Léonard and $O$. michelsonii till date (Ladipo et al., 2008). It was recorded that $O$. michelsonii was located as scattered solitary trees (African Plant Database, 2015) at the edge of the Guinean Forests, in the transitional forest zone bordering the East African Rift valley, probably close to Goma and Bukavu in the Democratic Republic of Congo (Figure 4). No scientific research publication exist for $O$. michelsonii, and it was only mentioned in two articles (see Leonard and Troupin, 1950; Ladipo et al., 2008). Likewise, the only herbarium collections for $O$. aubrevillei var. glabrescentifolia was made in 1938 and 1947 by J. Louis and J. Leonard respectively. The 


\section{Macrothink}

herbarium specimens were deposited in National Botanic Garden of Belgium. In summary, the tree is distributed in at least 12 countries in West and Central Africa (Figure 4).

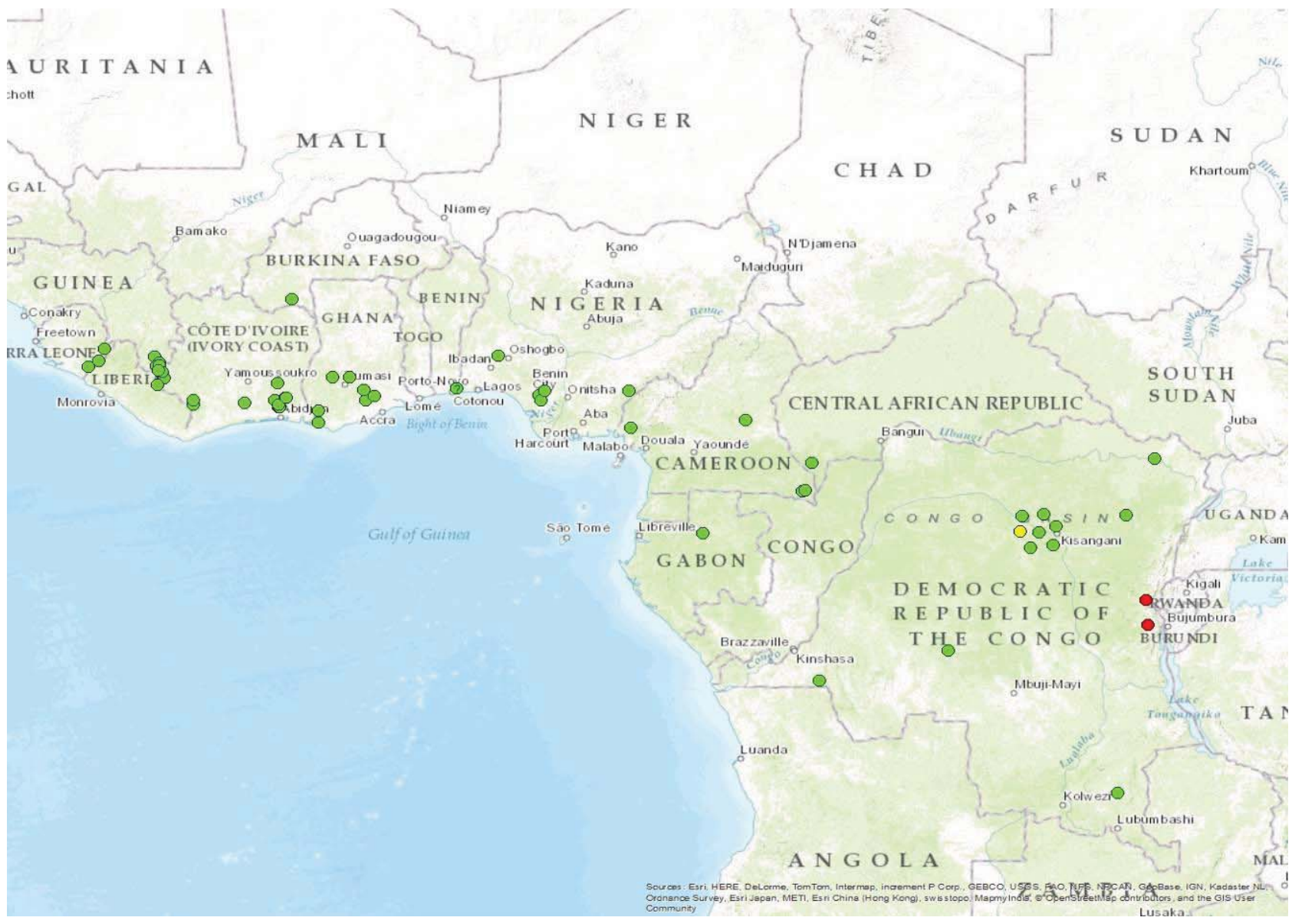

Figure 4. Map of distribution of Genus Okoubaka in West and Central Africa

(Green markers show the distribution of $O$. aubrevillei var aubrevillei in the region, while red and yellow markers in Democratic Republic of Congo illustrate the distribution of $O$. michelsonii and $O$. aubrevillei var. glabrescentifolia respectively. Question mark on the Benin Republic point indicate uncertainty of the tree location in the country). Basemap source: ESRI ArcGIS version 10.2 topography map.

\section{Ecological Significance of $O$. aubrevillei}

Perhaps the most important ecological significance of the tree is its hemi-parasitic potentials. Throughout its range, the species is locally reputed to kill other trees (Keay et al., 1964) and is often found in openings in the forests (Veenendaal et al., 1996a). The presence of haustoria on the roots of $O$. aubrevillei has been reported (Swaine and Hall, 1986; Veenendaal et al., 1996a). Veenendaal et al. (1996a) further reported the hemi-parasitic behavior of the tree starting from 6 months old seedlings, using haustoria to kill surrounding plants. They further suggest that the tree prefers nitrogen-fixing leguminous trees like Pericopsis elata (Veenendaal et al., 1996a). The tree is said to prevent any undergrowth forming beneath it - although some species are immune to the effect (Burkill, 1985). Hardie (1963) reported that no tree was found within 80 feet of a 60 feet Okoubaka tree, except for Myrianthus arborea, Musanga cecropoides and a woody Vernonia. In addition, Akotto et al. (2014) reported Cola attiensis growing closely to 
the tree stands in Akye country in southeastern Côte d'Ivoire. Veenendaal et al. (1996a) believed this parasitic strategy was to reduce the growth of neighbouring trees so as to give slow-growing $O$. aubvrevillei a competitive edge in a light-limited environment.

The tree's seed mass is large and thus Hawthorne (1995) suggested that the species is dependent on large animals such as forest elephants for its dispersal. To corroborate this, Hawthorne (1995) observed O. aubrevillei saplings in large forest gaps where elephant populations have been sighted. Therefore, "limited dispersal possibilities and a smaller number of large seeds are likely to decrease the number of encounters with potential hosts and a selective strategy would therefore seem less advantageous in the species-rich rainforest" (Veenendaal et al., 1996a). Furthermore, the tree was also reported to be a non-pioneer light demander (NPLD) tree (Okyeman Environment Foundation, 2003; Marshall and Hawthorne, 2012b). The tree was also observed to be a phorophyte for the epiphytes (Fig. 5). In addition, the leaves of the tree was reported to be a source of food to chimpanzees in Bossou, Republic of Guinea (Hockings, 2007), and the seeds and fruits are eaten by porcupines (Ladipo et al., 2008). Planting trials for the tree indicated that after about 10 years $54 \%$ of the plants had survived and had reached an average height of $4.2 \mathrm{~m}$ and a maximum height of $8.6 \mathrm{~m}$ (Ladipo et al., 2008).

Studies on species rarity is lacking in African tropical forest ecoregions, however ecological studies in the temperate regions suggest negative density dependence as one of the ecological factors that sustain rare species and prevent them from going extinct (Wright, 2002). In addition, $O$. aubreville $i$ was reported occupying open area in the forest (Veenendaal et al., 1996a) and as a NPLD (Marshall and Hawthorne, 2012b), there is strong indication that forest gap and openings in the forest canopy is important for its establishment and growth in the forest. This adaptation among tree species has been reported by several authors (Whitmore, 1978; Denslow, 1987; Bazzaz and Sipe, 1986). Furthermore, Veenendaal et al. (1996b) reported the significance of forest gap and edaphic factors on the seedling establishment and survival of some West African trees species. In view of this, its hemi-parasitic potential is probably a natural process to create open spaces for the tree to ensure its growth and establishment. Similarly, forest gaps associated with some stands could have been created by the tree employing its hemi-parasitic potentials.

Therefore, rarity and discontinuous spatial distribution of $O$. aubrevillei could be attributed to its low dispersal capacity due to relatively large seed mass, medium to low germination and inadequate forest gap that characterized naturally closed Guinean forests of West Africa. If the assumption that the tree seeds are dispersed by elephants is true, then decimation of elephant populations within the tree's range could be considered a causal factor for its rarity.

\section{Reproductive Biology and fecundity of $O$. aubrevillei}

The tree is monoecious, therefore it is likely that it undergoes self-fertilization (allautogamy), unless there is mechanism to avoid self-fertilization. Since the matured individuals are widely distant from each other in most cases, chances for cross pollination is very low. Though self-fertilization ensures the survival of widely spaced individuals of a species and maintains genetic stability of traits; it leads to inbreeding depression, low genetic variation and reduced biological fitness which are vital to evolutionary potential of a species in changing 


\section{MInstitute Macrothink $^{m}$}

Journal of Biology and Life Science ISSN 2157-6076 2015, Vol. 6, No. 1

environmental conditions. In Ghana and Côte d'Ivoire where pure stands of the tree are reported, it is possible that the tree could undergo mixed mating system. Mixed mating system has been reported in over $42 \%$ of flowering plants (Goodwillie et al. 2005). The tree flowers between May and July, and fruits in January of each year (Hutchinson and Dalziel, 1958; Poorter et al., 2004).

Since little is known about its pollination, it is assumed that pollination of $O$. aubrevillei flowers follows similar pollination types used by other West African trees, which in most cases, is either by ants (myrmecophily) or bats (cheiropterophily). Like other West African trees, the small greenish flowers of $O$. aubrevillei are not likely to attract birds for pollination. However, scientific investigations and studies are needed to provide accurate information on the tree's reproductive biology. Furthermore, inverse modelling (IM) is recommended for studying and modelling the tree's seed dispersal and fecundity (Jones and Muller-Landau 2008).

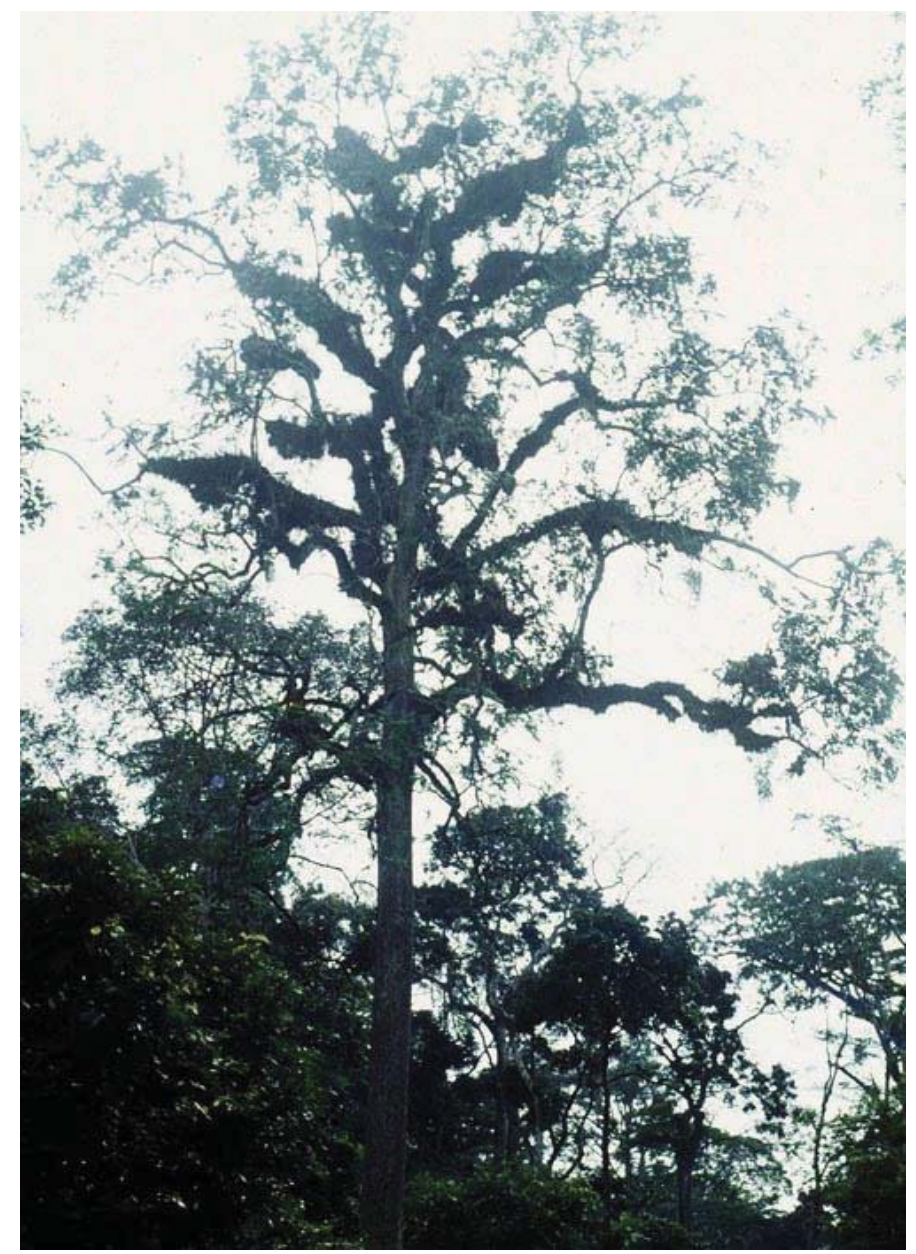

Figure 5. O. aubrevillei with epiphytes on it in Ghana (Source: M.D Swain, 1977)

\section{Ethnobotanical and Commercial use of O. aubrevillei}

\subsection{Ethnomedicine}

In all its native range, the tree is used for various medicinal purposes. The main parts used are the bark and the seeds. The bark is used for treatment of insanity (Osemeobo, 2007). van Andel 
et al. (2012) reported the use of the tree bark and seed for treatment of convulsions, as an aphrodisiac, for rituals and prevention of miscarriage. Idu and Onyibe (2007) reported the use of the bark and leaves for reducing swollen testicles (orchitis) among Edo people of Nigeria. In Akoase, Southern Ghana, the seeds were used for ante and postal natal care, and O. aubrevillei branch is tied on a broken limb along with other plants for the healing of the limbs (Myren, 2011). Burkill (2000) reported the use of the bark infusion or maceration in water for the treatment of skin problems (including those caused by syphilis and leprosy), while external applications of the bark preparations is used to counteract poisoning. Furthermore, the bark maceration is taken orally to treat tachycardia and is taken as a vapour bath or as nose drops to cure oedema (Burkill, 2000). The bark is also reported to be used as antidotes for venomous stings and bites etc., and in the treatment of dropsy, swellings, gout, heart, leprosy and venereal diseases. In Ghana, the seed of $O$. aubrevillei is being used for the treatment of boils (Dovi, 2013). Kone et al. (2008) reported the use of the tree for antiseptic treatment of wounds.

In addition, the pounded bark of Milicia excelsa mixed with the kernel of Okoubaka aubrevillei fruits is taken internally in alcohol to cure piles (FAO, 1986; Iwu, 2014). Ita and Offiong (2013) compiled 6 polyherbal mixtures involving Okoubaka aubrevillei barks for the treatment of malaria fever, elephantiasis, poisoning and abscess. The authors further noted the high demand and use of the tree bark for diverse medicinal purposes. In addition, the tree is also reported to be used for treating intestinal infection, food intolerances and elimination of metabolic wastes. It is also used in porridge in combination with other plants to strengthen children's bones and allow them to walk early (Myren, 2011). In addition, the European Agency for the Evaluation of Medicinal Products (EMEA, 2000) reported that the pulverized bark of O. aubrevillei is used prophylactically at doses of several teaspoons per day by the native Africans for treatment of alimentary poisonings and infections of the gastrointestinal tract. Furthermore, O. michelsonii bark is taken as a febrifuge and tonic (Neuwinger, 2000; Ladipo et al., 2008).

\subsection{Okoubaka in Modern Medicine}

In Nigeria, the stem bark is used for the production of modernized anti-malarial herbal drug, Maloff-HB (Ogunkunle et al., 2014). However, major use of the tree products in modern medicine is in Europe and the USA, where the bark is used extensively for the production of homeopathic drugs and in veterinary medicine. For instance the European Agency for the Evaluation of Medicinal Products (EMEA, 2000) has reported its use in homeopathy (man and animal) with no adverse effect. In studies, Okoubaka has demonstrated its potentials to stimulate the body's defense mechanisms against poisonings. The bark extract has been proven to be effective against stomach upsets and body reactions caused by food-poisoning, pesticide poisoning, many self-poisoning (auto toxic) diseases, lethargy, depression and allergies. This is because Okoubaka helps the body regain control and normalizes the immune system to fight off other potential aggressors. In addition, the tree is infused into topical solutions which are utilized to treat skin problems resulting from leprosy and syphilis, as well as to counter the effects of external poisoning. Minter (2009) listed Okoubaka as one of the top 300 herbal medicinals sold in the UK. In Germany the tree bark is especially known in paediatric medicine and some colleagues use it more frequently than Nux-vomica for gastro-intestinal disorders in dogs (Kohlrausch, 2011). 


\section{Mll Macrothink}

Journal of Biology and Life Science ISSN 2157-6076 2015, Vol. 6, No. 1

The history of the medicinal use of this plant in Europe involved Dr. Magdalena Kunst from Frankfurt, a homeopath, being told by a West African native of the uses of the tree to neutralize poisons in food. The curious Dr. Kunst and Dr. Schwabe conducted experiments which validated the efficacy of the tree's bark in homeopathy in 1972, and they published around 80 case histories in the German magazine, Allgemeine Homöopathie Zeitschrift (AHZ) (Kohlrausch, 2011).

Homeopathic drugs containing O. aubrevillei bark extracts include Allergy relief Pollinosan (A. Vogel/Bioforce), Allergy relief (Bioforce USA), Okoubaka aubrevillei (VSM), Pleo Oku (Okubasan) by Biomed, Detox intestinum (Hevert, USA), Okoubaka drops (Pekana), Rubus (Biomed), Eubioflor 1 (Guna Biotherapeutics), Pollinosan Luffa nasal spray (A. Vogel/Bioforce), Pollinosan hay fever (A. Vogel/Bioforce), Okugest tablets (VSM). Furthermore, several veterinary diseases are being treated using varying preparations of the tree bark active ingredients. Several pharmacological concentrations from the tree bark are used for the drug synthesis and for pharmaceutical research. Such concentrations include Okoubaka C200, C30, D12 and C12 granules among others. Teut et al. (2013) screened the homeopathic efficacy of Okoubaka $\mathrm{C} 12$ on volunteer subjects.

\subsection{Symbolism and Associated Taboos}

O. aubrevillei is considered a sacred tree and used for magical purposes (Marshall and Hawthorne, 2012a) in most of its locations in West Africa. EMEA (2000) reported that the tree is used as a fetish by medicine men in West Africa. Azeez et al. (2010) listed the tree as one of the sacred trees among Benin people in Nigeria, while Isikhuemen and Iduozee (2008) reported that the tree is considered the king of the forest in rural Edo State, Nigeria.

It is reported to be worshipped as a god in Iwara town, Osun State (Ladipo et al., 2008) and some parts of Edo State, Nigeria. In Nigeria, some traditional incantations noted that it is the only tree that can never be struck by lightning (Akinpelu, 2009). Furthermore, Yoruba people of Nigeria believe powerful spirits in the tree are responsible for preventing other plants from growing near it, thus increasing the more respect for the tree. The tree is used for incantations for crop harvest, preparation of traditional medicines, and prevention of rainfall or forcing rain to fall for cultural ceremonies and festivals (Osemeobo, 2007), while all parts of the tree are used to ward off evil spirits and treat sundry ailments (Isikhuemen and Iduoze, 2008). In southern Nigeria, it is an important tree in religious ceremonies (Ladipo et al., 2008).

The Asante people of Ghana considered Odii (O. aubrevillei) among others as having spirits (Cobbinah et al., 1999). van Andel et al. (2012) reported that the tree bark is sold in Ghanaian herbal markets for making rituals. Furthermore, the tree is considered a sacred tree and located in sacred forests/shrines in Akoase, Southern Ghana. It is believed that the spirit named Motia lives in the tree (Myren, 2011). Sometimes, people had to be completely naked before they can visit the tree, and had to make offerings before they can collect the bark (Myren, 2011). In Nzema (Ghana), the tree is used for spiritual protection, treat spiritual problems such as frequent still births, bad luck, bad dreams and correct bad marriages (Myren, 2011). In addition, Okoubaka aubrevillei is reported to be used symbolically to ward off evil spirits in Côte d'Ivoire (Cunningham, 2000). 
The use of the tree for spiritual protection was reported by Maundu et al. (2006) and many publications. Myren (2011) reported the use of the tree bark for spiritual protection in Akoase and Nzema, Ghana. Hardie (1963) reported the use of the tree in making charms to drive away evil from a house, and also to inflict a curse upon an enemy among Bini people. Ita and Offiong (2013) reported the use of the bark as part of the polyherbal formulations for wading off witchcraft and protection from charms in Cross River State, Nigeria. EMEA (2000) noted its symbolical use for wading off evil spirits. Burkill (1985) reported that West African natives place a piece of the bark in a house to drive out spirits and robbers and offered protection against car accidents.

As a result of the veneration given to the tree, several taboos, traditional practices and beliefs are held for the tree, which include:

1. The harvester must appease the spirit of the tree with libations or rituals before approaching the tree for harvesting (Isikhuemen and Iduoze, 2008; Myren, 2011; Falconer, 1992; Good, 1987), and sometimes, the harvester must approach the tree with complete nakedness (Myren, 2011; Hardie, 1963). After harvesting, the harvester is strongly advised to quickly run away from the tree and dress up so that in case the tree spirits are not satisfied with the appeasement, and pursues the harvester, they may not be able to identify him when fully dressed (Oliver-Bever, 1960).

2. Items used for libations include portions of kola nut, white yam, cocoyam and plantain, two cowrie shells, a piece of white drill cloth and a quantity of chalk (Hardie, 1963).

3. The bark may be harvested by day or at night - never at sunrise or sunset when the tree 'spits poison' (a dark poisonous liquid) (Hardie, 1963). In addition, the harvester must not harvest the bark in his own shadow (Myren, 2011).

4. The Bini (Benin) people of Nigeria believe that Myrianthus arboreus and Musanga cecropioides (the only plants that grow beside Okoubaka) are the wife and servant of the tree respectively (Hardie, 1963).

5. It is believed in Ghana that dwarfs are associated with the area where the tree grows (Owusu-Sekyere, 2008).

6. The bark of the tree can only be harvested with a wooden batten, and under no circumstances may a machete or metal implement be used. This rule is applicable in the entire West African region (Hardie, 1963; Osemeobo, 2005)

\subsection{Pharmacology}

Wagner et al. (1985) reported 6 different catechins which have been isolated from the tree's bark. These catechins include $(+)$-catechin and $(+)$-gallocatechin, as well as $\beta$-sitosterol and stigmasterol. They further reported that the bark has antimicrobial and immuno-stimulating properties that are attributed to phenolic compounds (Wagner et al., 1985). Due to its contents of tannin, catechols and phenylcarbonic acids, this plant is a typical tannin drug with strong phagocytosis promoting effects. The tree leaf was reported to contain glycosides, saponins, steroids, while the root/trunk bark contains alkaloids. Furthermore EMEA (2000) reported sterines (beta-sitosterine, stigmasterine, sterine acetate), amino acids, tannins and catechins 


\section{Macrothink}

Journal of Biology and Life Science ISSN 2157-6076 2015, Vol. 6, No. 1

(catechin, gallocatechin, epicatechin, epigallocatechin, epicatechin-gallate, epigallocatechin-gallate), gallic acid, pyrogallol and di-and triglycerides.

In a study by Dovi (2013), the seeds of Okoubaka aubrevillei extracts showed a scavenging ability with an $\mathrm{IC}_{50}$ of $731.0987 \mu \mathrm{g} / \mathrm{ml}$ and $865.6633 \mu \mathrm{g} / \mathrm{ml}$ for methanolic extract and hydro-ethanolic extract respectively. Furthermore, the phenol content of hydro-ethanolic and methanolic extracts of $O$. aubrevillei seeds was quantified $(0.1707 \mathrm{mg} / \mathrm{ml}$ and $0.2573 \mathrm{mg} / \mathrm{ml}$ respectively); while the seed extracts of the tree showed considerable antimicrobial activities against Staphylococcus aureus and Bacillus substilis (Dovi, 2013). The methanolic extracts of the seeds were found to contain alkaloids, while the hydro-ethanolic extracts contain both saponins and alkaloids (Dovi, 2013). Furthermore, Kone et al. (2008) investigated in vitro antimycobacterial potentials of total aqueous extracts of $O$. aubrevillei against 7 strains of Mycobacterium ulcerans from different regions. In Africa the wood and the dried and pulverized bark of $O$. aubrevillei is currently being studied because it could possibly have a pancreatic or similar enzyme action. (Nacci, 2010).

\subsection{Other Uses}

The tree yields quality wood which is used in forestry. The wood is sometimes used for construction or as firewood (Ladipo et al., 2008). O. aubrevillei stem bark is used as fish poison in Liberia (Neuwinger, 2004), while the seeds are used ethnobotanically as insecticide among the Asante people of Ghana (Cobbinah et al., 1999).

\section{Conservation and Management of $O$. aubrevillei}

\subsection{Conservation Status of Okoubaka}

Since there is no globally accepted conservation rating for this species, the only available ratings are the published ones from some of the native countries. All of the authors that attempted to classify the tree's conservation status noted that the tree is faced with threats in all its native range. Conservation status for the tree ranges from "vulnerable" (Ladipo et al., 2008; Maundu et al., 2006); "endangered" (Isichei, 2010; Okyeman Environment Foundation, 2003) and in Côte d'Ivoire's Union Postal stamp (Fig. 6); "rare" (Hardie, 1963; Isikhuemen and Iduozee, 2008); and "critically endangered" (Borokini and Clement, 2012). In addition, concluding from their studies, van Andel et al. (2014) recommended the tree be given an IUCN status of vulnerable A3cd.

Borokini and Clement (2012) noted that the tree bark was relatively expensive in visited herbal market in Ibadan, while the herb sellers claimed it is scarce, just as reported scarce by other medicinal vendors across West Africa (Burkill, 1985; Cunningham, 1997; van Andel et al., 2012). Isikhuemen and Iduozee (2008) reported that very few stands of the tree is remaining in the wild, and the ones they sighted were actually young coppices (Fig. 3). Osemeobo (2005, 2007) estimated that less than 20 standing trees of this species remain in Nigeria. In Ghana, the tree is considered "endangered" and assigned "gold stars" indicating that it requires conservation priority after species with highest priority, designated "black stars" (Okyeman Environment Foundation, 2003), while CUC (2010) listed it with "blue stars", which a conservation rating just below gold stars. Yet, van Andel et al. (2014) reported $241 \mathrm{~kg}$ of the 


\section{MInstitute Macrothink $_{\text {Int }}$}

Journal of Biology and Life Science ISSN 2157-6076 2015, Vol. 6, No. 1

tree products offered for sale in Ghanaian medicinal plant markets. In a survey, Okoubaka aubrevillei ranked the highest among over 100 trees used for NTFPs in 7 communities (Barpa, Bentor, Gbapa, Makinto, Sehyigeh, Vanyampah and Zolowee) in Nimba Western Area, Liberia and therefore should be given priority for protection (URS, 2013). The SDM analysis indicate a very narrow suitable habitat area of less than $4 \mathrm{~km}^{2}$ for the tree in Benin Republic (van Andel et al., 2014).

The genus Okoubaka has just two species and a variety, all of which have a relatively limited geographical range, and based on the records available for this species, the population of $O$. aubrevillei in its range is probably less than 250 mature individuals. Though the distribution range is more than $100 \mathrm{~km}^{2}$, it has been shown to be rare in all its reported locations, while high demand for its bark and seeds for medicine as well as its highly priced wood has influenced the decimation of the populations in all its range. This description of the state of $O$. aubreville $i$ fits into the IUCN status (IUCN Categories and Criteria, version 3.1, IUCN, 2001) of "critically endangered" species based on criteria B2bc, $\mathrm{C} 1$ and $\mathrm{C} 2 \mathrm{a}$. The status of $O$. michelsonii also meets IUCN Categories and Criteria for critically endangered rank based on criteria B2ac, C2a and D.

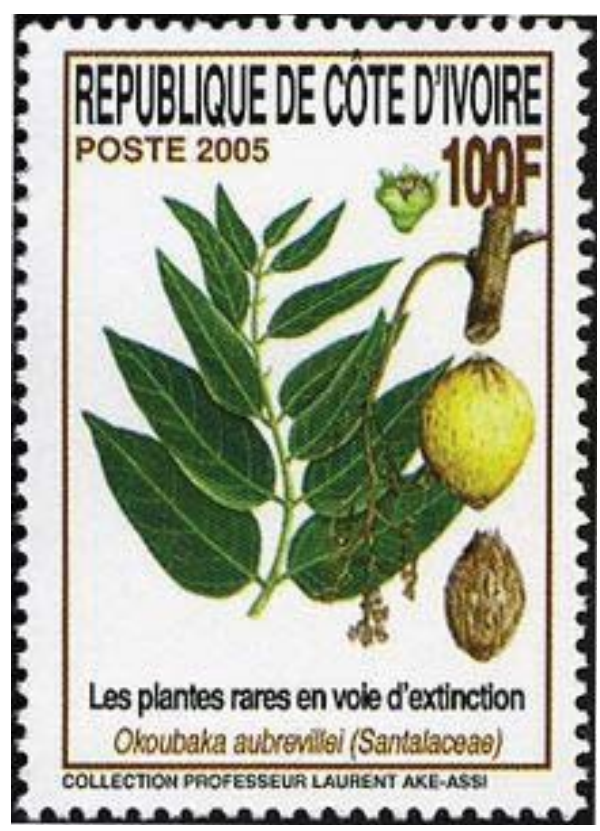

Figure 6. Image of Okoubaka aubrevillei on the Union Stamp of Côte d'Ivoire

\subsection{Current Management and Protection of Okoubaka}

There appears to be no specific conservation programs for the tree in all its ranges. Ladipo et al. (2008) reported the attempt to propagate the tree in DRC, while Burkill (1985) reported a national ban on the possession or sale of Okoubaka bark in Liberia some decades ago. However, there is no evidence to support the enforcement of the law. In few locations, as described in the geographical locations, the tree is located in protected areas such as in Sapoba FR, Ehor FR, Uhronigbe FR (Nigeria), Atewa Range FR (Ghana), Parc National de Taï, forests of Sanaimbo, Yapo Forest reservation (Côte d'Ivoire), Lobeke reserve, Deng Deng Forest (Cameroon), Ituri Forest (DRC), Dzanga Sangha Protected Area complex (Central African Republic) and Gola 


\section{$\Lambda$ Macrothink}

Journal of Biology and Life Science ISSN 2157-6076 2015, Vol. 6, No. 1

Forest Reserves (Sierra Leone). This tree was not reported in any ex-situ conservation site in all the countries where it is found. Although van Andel et al. (2014) reported that its natural habitat (primary rainforest) in eastern Liberia to Southwest Ghana and the Congo Basin is $73 \%$ intact, data used for that study did not include some of the countries, such as Nigeria and Gabon where occurrence have also been reported. Furthermore, it is believed that the tree population is declining rapidly, as the tree is now absent in locations where herbarium samples were collected in the 1950s.

Due to veneration and dendrolatry practices on the tree, traditional protection seems very strong and effective, especially in areas where traditional institutions are strong in West African countries. Furthermore, the general practice of pre-harvest libations and bark harvesting with wooden batten offers some form of traditional protection and reduction in harvest pressures. In addition, in many parts of West Africa where forests are cleared for farming, sacred trees are spared from destruction hence, Mafimisebi and Oguntade (2010) reported the protection of $O$. aubrevillei in farmlands. Hardie (1963) reported traditional prohibition of bark harvesting on tree among Bini people of the present Edo State, Nigeria.

\subsection{Threats to Okoubaka}

The tree is faced with both natural (biological) and anthropological threats. Seed germination for Okoubaka seedling regeneration is extremely poor (De la Mensbruge, 1966; Hawthorne, 1995), as trials carried out in National Centre for Genetic Resources and Biotechnology, Ibadan in the 2000s yielded only 3 seedlings (NACGRAB, 2004), while Ladipo et al. (2008) noted that the tree has poor natural regeneration ability and the seeds are eaten by porcupines. Based on seed classification by Roberts (1973), O. aubrevillei seeds are believed to have recalcitrant behavior and Veenendaal et al. (1996a) recommended planting freshly collected fruits.

Perhaps the major concern for the tree is its uncontrolled exploitation for seed and bark which are used in both ethnomedicine and modern medicine. van Andel et al. (2012) reported that the tree bark is one of the most frequently sold species in Ghanaian herbal markets, while Hardie (1963) reported scarring and heavy debarking on a stand in Sapoba FR in Nigeria in spite of traditional laws prohibiting bark harvesting. Myren (2011) noted that a tree stand in the sacred forests/shrines in Akoase, Southern Ghana was felled. Isikhuemen and Iduoze (2008) cited harvest pressure and habitat loss as threats to the tree. The tree is under serious threat as a result of habitat loss and deforestation in Ghana, Nigeria and Côte d'Ivoire, to the extent that vendors and harvesters reported it to be scarce. Though considered a sacred tree, experts in Côte d'Ivoire claim that the tree is felled to allow for farming in many areas. This is in contrast to the general practise of sparing sacred trees when clearing land for farming.

Local and international markets abound for the tree bark and seed, with most international markets and sources for European homeopathic drug manufacturing originating from Cameroon, Ghana and Côte d'Ivoire. Heavy exploitation was reported in Nigeria, Ghana and particularly Cameroon which feeds the European medicine markets (Good, 1987). While local information indicate that the bark is sold for about US\$ 20 per $\mathrm{kg}$, reports on the international trade of this species is lacking (Ladipo et al., 2008). Bark harvesting in medicinal trees is very common in the entire African region where ethnomedicine is predominant, but tree recovery 
after extensive debarking varies from species to species with most of the tropical trees exhibiting slow recovery (Fashola and Egunyomi, 2005).

While traditional beliefs is the main form of protection for this species, traditional institutions are losing their significance and respect in many parts of West Africa. The fears for the taboos that had helped protected some sacred trees are no longer relevant, while scientific research has explained and de-mystified some "mysterious phenomena" surrounding some sacred trees, including the hemi-parasitism potentials of Okoubaka. As a result of scientific enlightenment, relative economic hardship and demand for its wood, harvesters could easily approach the tree and harvest its parts without restriction in many places. Myren (2011) reported the felling of an Okoubaka stand even within a sacred forest in Akoase, Ghana. In spite of traditional prohibition of bark harvesting among Bini people of Nigeria, Hardie (1963) sighted stands of the tree in Sapoba FR with heavy debarking and scarring. In addition, Marshall (2011) predicted that the 2 stands in the ridge top forest in Liberia would be negatively impacted by the proposed ridge top mining operations.

The populations of the tree appears to have declined sharply in the last 60 years, as many locations in Cameroon, Ghana, Sierra Leone and Côte d'Ivoire where herbarium samples for the tree was collected in the 20th century are currently invalid because the tree is absent in those locations. As a result, over $25 \%$ of the tree population is estimated to have been lost in the last 50 years. Although the population of matured individuals for this tree is unknown, field experience indicate as low as less than 100 matured trees across the entire West and Central Africa, which are widely distant from each other. Being a monoecious plant, this could point to high inbreeding depression from self-fertilization, low genetic variation and reduced biological fitness. As a result, its chances of adapting to changing climatic conditions is low. Low genetic variation has been reported among other monoecious species of Santalaceae (Gonzalez-Perez et al., 2013).

Despite the fact that the tree is reported in protected areas in many parts of its ranges, strict protection and management of protected areas have been characterized by widespread encroachment, poor staffing, inadequate funding, presence of enclave villages, land conversion to farming and several other illegal activities in Nigeria (Meduna et al., 2009; Oseni, 2007), and other African countries (Struhsaker et al., 2005; Jachmann, 2008; Weladji and Tchamba, 2003).

\section{Recommended Conservation and Research Actions}

Several authors have given recommendations on urgent actions that need to be taken for the conservation of this species. Cunningham (1993) recommended carrying out "damage assessments for exported species such as Okoubaka aubrevillei, Garcinia afzelii and G. kola in West Africa, especially Ghana, Côte d'Ivoire, Nigeria." He further recommended studies on the genetic diversity and the population biology of $O$. aubrevillei, which would provide adequate information for the conservation and management of the species. Veenendaal et al. (1996a) recommended raising seedlings from freshly collected seeds for subsequent establishment in protected areas, as well as population studies on the species. Ladipo et al. (2008) advocated for monitoring of the sales and exportation of the species, as Ariz. Univ. Office of Arid Land Studies (1981) also called for its conservation. Borokini (2014) recommended IUCN 
conservation rating for this species while Marshall and Hawthorne (2012a) reported that indigenous communities expressed concern for the conservation of the tree in Liberia.

In addition to these recommendations on required research efforts on this species, the following recommendations are also necessary:

1. There is an urgent need to include O. aubrevillei in CITES listing for countries with active exportation to Europe, especially Cameroon and Ghana. Process of doing this will require adequate statistics of international trade for the species. This will help enhance conservation management and protection for the tree.

2. Research is required to study the recovery potentials of this species to debarking

3. While there are conflicting reports on the germination rates of the seed, there would be the need to conduct standard silvicultural trials on the seeds to determine its germination success. In the same vein, studies would be important to predict the seed longevity with the use of seed longevity models and to predict the morphological characters of the seed germplasm of $O$. aubrevillei using appropriate Seed Digital Imaging tools. This will provide foundational knowledge on the best practices for the tree's seed management.

4. It will be beneficial to develop micro-propagation (tissue culture) protocols for mass production of plantlets from different provenances. However, the seedlings or plantlets produced from these experiments should be established in protected areas.

5. Furthermore, anatomical studies on the leaves, receptacle, flowers and other plant parts of taxonomical interests should be done, while existing information should be revised, including the physiology of the tree. This was supported by earlier submission of Nickrent and Der (2008) indicating disagreement on the homology of the perianth lobes.

6. Most of the knowledge on the tree is in the repository of the local people in all its range, which Osemeobo (2005) reported it being held in secrecy. This was also observed in Liberia (URS, 2013) where the communities refused to show the tree stands to the scientists. Similar situation was also observed in Cross River State, Nigeria. Therefore, collaborative studies should be carried out among botanists, ethnobiologists and the indigenous people in order to expand knowledge base on the tree, as well as the conservation of the tree. However, indigenous knowledge should be carefully protected.

7. The spatial distribution pattern of the tree (Fig. 4) suggests a disjunct distribution within West and Central Africa, however exploration may be required within the Guinean forest-savanna mosaic ecoregion in the Dahomey Gap (Togo and Benin Republic) and Congo Republic, especially in forest gaps and slopes which provide perfect sanctuary for the tree. Prospects for stands of this tree in new locations are further amplified by the new locations - Burkina Faso and Central African Republic. Aside explorations, working with herb sellers, harvesters and local communities in addition to herbarium curators have proved very effective in locating plants.

8. Though the tree has been established as hemi-parasite, further studies is required on the chemical ecology of patterns of its parasitic potentials, and the anti-parasitic potentials in Myrianthus arboreus and Musanga cecropioides is also worth investigating. 


\section{Macrothink}

Journal of Biology and Life Science ISSN 2157-6076 2015, Vol. 6, No. 1

9. Foresters may want to investigate the volume prediction and inventory analysis for all the stands of the tree species, while plant physiologists may have more information to share with the scientific world on the leaf area and general physiology of the tree, with respect to its hemi-parasitic nature.

10. While Cunningham (1993) recommended studying the population biology of this species, the author wishes to emphasize the need to study population dynamics, population viability analysis, dispersal capacity and the relationship between density and population growth rate (pgr) of $O$. aubrevillei within its native range.

11. With a recent placement of the tree in a new family, Cervantesiaceae (Dar and Nickrent, 2008; Nickrent et al., 2010), further taxonomic investigations on the tree would be needed to confirm or negate this.

12. Scientific knowledge on the reproductive biology of this tree is extremely crucial to conservation planning and management of the tree. Studies are therefore, needed to provide the much needed information on its flower morphology, pollination type, fertilization type, fruiting and dispersal.

While urgent efforts need to be taken in form of conservation and research studies, various stakeholders in the value chain of this tree should be identified and actively involved. Importance should be attached to the involvement of the indigenous people, while relevant European medicine manufacturers should be encouraged to finance research and conservation efforts on the tree.

\section{Conclusion}

This paper have provided a compendium of baseline scientific information on this rare, threatened, hemi-parasitic and medicinal tropical tree species. New hypotheses regarding its hemi-parasitic potentials were provided, additional locations were documented, and the entire geographical distribution of the genus was represented on topo-geographic map. It is expected that this article will help provide information base for a globally-accepted conservation ranking for the species, and stimulate further research on the species.

\section{Acknowledgement}

The author wishes to acknowledge the constructive criticism and valuable suggestions from Dr. Mary Peacock of Department of Biology, University of Nevada Reno; relevant technical information provided by Ms. Cicely Marshall; and technical assistance from Mr. Eric Purpur of GIS lab, University of Nevada Reno is also appreciated.

\section{References}

Abbiw, D. K. (1990). Useful plants of Ghana. West African uses of wild and cultivated plants. Intermediate Technology Publications, London and Royal Botanic Gardens, Kew. 337 pp.

African Plants Database (2015). African Plant Database version 3.4.0. Conservatoire et Jardin botaniques de la Ville de Genève and South African National Biodiversity Institute, Pretoria, "Retrieved [January 2015]", from <http://www.ville-ge.ch/musinfo/bd/cjb/africa/>.

Akinpelu, O. A. (2009). 'Posers on the reality of Igi Nla (Nnune Ebe?)' The Nig. Field. 7. 92 - 
96.

Akotto, F. O., Alphonse, A. K., François, M. D., Josselin, K. K., Albert, Y. K., \& Kamanzi K. (2014). Soil landscape and stand conditions in Cola attiensis in Côte d'Ivoire. Int. J. Biosci. 4(5). 102-113. http://dx.doi.org/10.12692/ijb/4.5.102-113

van Andel, T., Myren, B., \& Onselen, S. V. (2012). Ghana's herbal market. J. Ethnopharm. 140. 368-378. http://dx.doi.org/10.1016/j.jep.2012.01.028

van Andel, T., Croft, S., van Loon, E.E., Quiroz, D., Towns, A.M., Raes, N. (2014). Prioritizing West African medicinal plants for conservation and sustainable extraction studies based on market surveys and species distribution models. Biol. Conserv. 181. 173-181. http://dx.doi.org/10.1016/j.biocon.2014.11.015

Arizona. University Office of Arid Land Studies (1981). Draft environmental profile on United Republic of Cameroon. Document no: PN-AAJ-626. Arid Lands Information Center, Office of Arid Lands Studies, University of Arizona, Tucson, Arizona. 81pp.

Aubréville, A., \& Pellegrin, F. (1937). Deux nouveautés de la Côte d'Ivoire. Bull. Soc. Bot. Fr. 84. 390-393. http://dx.doi.org/10.1080/00378941.1937.10837397

Aubréville, A. (1959). La flore forestière de la Côte d'Ivoire. Deuxième édition révisée. Tome premier. Publication No 15. Centre Technique Forestier Tropical, Nogent-sur-Marne, France. $369 \mathrm{pp}$.

Azeez, I. O., Ikponmwonba, O. S., Popoola, L., \& Amusa, T. O. (2010). Land use activities among forest environments' dwellers in Edo State, Nigeria: Implications for livelihood and sustainable forest management. Int. J. Soc. For. 3(2). 164-187

Balinga, M., Moses, S., \& Fombod, E. (2006). A preliminary assessment of the vegetation of the Dzanga Sangha Protected Area Complex, Central African Republic. WWF, Smithsonian Institution, Forests, Resources and People \& CARPE. 124pp.

Bazzaz, F. A., \& Sipe, T. W. (1986). Physiological ecology, disturbance, and ecosystem recovery. In Schulze, E.D. and H. Zwölfer (eds.) The Potentials and Limitations of Ecosystem Analysis. Springer-Verlag, New York. 435 pp.

Bluskova, G., Kitin, P., Beeckman, H., \& Brezin, V. (1995). Structure, properties and possibilities for utilization of the wood of Okoubaka aubrevillei (Santalaceae). In: V. Brezin, I. Yovkov, B. Dinkov, E. Pavlova, V. Vasilev, \& I. Draganova (eds.) 70 Years forestry education in Bulgaria. Vol. 2. Higher Institute of Forestry, Sofia, Bulgaria.

Borokini, T. I., \& Clement, M. (2012). Ethnomedicinal significance and conservation status of tree barks sold in herbal markets in Ibadan, Southwest Nigeria. Int. J. Curr. Res. 4(3). 31-36.

Borokini, T. I. (2014). A Systematic Compilation of IUCN Red-listed Threatened Plant Species in Nigeria. Int. J. Env. Sci. 3(3). 104-133

Burkill, H. M. (1985). The Useful Plants of West Tropical Africa, Vol. 1, Families A-D, Royal Botanical Gardens, Kew. 960 pp. 


\section{MInstitute Macrothink $_{\text {Institis }}$}

Journal of Biology and Life Science ISSN 2157-6076 2015, Vol. 6, No. 1

Burkill, H. M. (2000). The Useful plants of West Tropical Africa. 2nd Edition. Volume 5, Families S-Z, Addenda. Royal Botanic Gardens, Kew, Richmond, United Kingdom. 686 pp.

Cobbinah, J. R., Moss, C., Golob, P., \& Belmain, S. R. (1999). Conducting ethanobotanical surveys: an example from Ghana on plants used for the protection of stored cereals and pulses NRI Bulletin 77 (Working Paper), Natural Resources Institute, Chatham, UK. 15 pp.

Codjia, J. T. C., \& de Boer, J. J. (2014). Medicinaal hakhout onder de Oliepalm. Centre International d'Ecodéveloppement Intégré, Benin Republic and Vitis-Idaea, The Netherlands.

CUC (Certifications Forestry Certification) (2010). CUC Locally Adapted Standard for Forest Management Assessments in Ghana. CUC Adapted Standard for Ghana Version 08 (DEC 2010). Control Union Certifications Forestry Certification, The Netherlands. 73pp.

Cunningham, A. B. (1993). African medicinal plants: setting priorities at the interface between conservation and primary healthcare. UNESCO People and Plants Working Paper 1, Paris, France. 53.

Cunningham, A. B. (1997). An Africa-wide overview of medicinal plant harvesting, conservation and health care. Non-wood For. Prod. 11. 116-129.

Cunningham, Anthony B. (2000). People and Plants. Available at: http://www.rbgkew.org.uk/peopleplants/wp/wpl/intro.htm

Datte, Y. J., N'Guessan, B. B., Joulia, E. D., D’Horpock, A. F., \& Ehile, E. E. (2007). Influence de Sacoglottis gabonensis (Baille) urban et de Okoubaka aubrevillei Normand et Pellegrin sur la croissance in vitro de Mycobacterium ulcerans. Le pharm. d'Afr. 206. 17-22

Denslow, J. S. (1987). Tropical Rainforest Gaps and Tree Species Diversity. Ann. Rev. Ecol. Syst. 18, 431-451. http://dx.doi.org/10.1146/annurev.ecolsys.18.1.431

Der, J. P., \& Nickrent, D. L. (2008). A Molecular Phylogeny of Santalaceae (Santalales). Syst. Bot. 33(1), 107-116. http://dx.doi.org/10.1600/036364408783887438

Dovi, E. (2013). Comparative studies on the in vitro antioxidant and antimicrobial properties of methanolic and hydro-ethanolic plant extracts from five medicinal plant parts of Ghana. A thesis submitted to the Department of Chemistry, College of Science and the School of Graduate Studies, Kwame Nkrumah University of Science and Technology in partial fulfilment of the requirement for the award of the Degree of Master of Philosophy (Analytical Chemistry). $112 \mathrm{pp}$.

EMEA (European Agency for the Evaluation of Medicinal Products) (2000). Okoubaka aubrevillei. Summary report. The European Agency for the Evaluation of Medicinal Products. Veterinary Medicines Evaluation Unit, United Kingdom. EMEA/MRL/673/99-FINAL. http://www.ema.europa.eu/docs/en_GB/document_library/Maximum_Residue_Limits_-_Rep ort/2009/11/WC500015212.pdf

ESRI (Environmental Systems Research Institute) (2013). ArcGIS Desktop: Release 10. Environmental Systems Research Institute. Redlands, CA. 


\section{MInstitute Macrothink}

Journal of Biology and Life Science ISSN 2157-6076 2015, Vol. 6, No. 1

Falconer, J. (1992). Non-timber forest products in southern Ghana: a summary report. ODA Forestry Series No. 2, UK Overseas Development Authority, London. 23pp.

FAO (Food and Agricultural Organization) (1986). Some medicinal forest plants of Africa and Latin America. FAO Forestry Paper no 67. Food and Agricultural Organization of the United Nations, Rome.

Fasola, T. R., \& Egunyomi, A. (2005). Nigerian usage of bark in Phytomedicine. Ethnobot. Res. Appl. 3, 073-077.

GBIF (Global Biodiversity Information Facility) (2010). Global Biodiversity Information Facility version 1.3.1. http://www.gbif.org/ Accessed January 13, 2015.

González-Pérez, M.A., Batista, F.J., \& Sosa, P.A. (2013). Conservation genetics in two endangered endemics from the Canary Islands, Helianthemum gonzalezferreri Marrero (Cistaceae) and Kunkeliella subsucculenta Kämmer (Santalaceae): different life histories that involve different management strategies. Plant Syst Evol 299, 1981-1990. http://dx.doi.org/10.1007/s00606-013-0852-4

Good, C. M. (1987). Ethnomedical systems in Africa: patterns of traditional medicine in rural and urban Kenya. The Guilford Press, New York NY. 354 pp.

Goodwillie, C, Kalisz, S, \& Eckert, C.G. (2005). The evolutionary enigma of mixed mating systems in plants: Occurrence, theoretical explanations, and empirical evidence. Annu. Rev. Ecol. Evol. Syst. 36, 47-79. doi:10.1146/annurev.ecolsys.36.091704. 175539

Gosline, G., \& Malécot, V. (2011). A monograph of Octoknema (Octoknemaceae - Olacaceae s.1.). Kew Bull. 66, 367-404. http://dx.doi.org/10.1007/s12225-011-9293-9

Hallé, F., \& Oldeman, R. A. A. (1970). Essai sur l'architecture et dynamique de la croissance des arbres tropicaux. Masson and Co., Paris, 178pp.

Hallé, F, Oldeman, R. A. A., \& Tomlinson, P. B. (1978). Tropical Trees and Forests. An Architectural Analysis. Springer-Verlag, Berlin. 441 pp.

Hallé, N. (1987). Okoubaka Pellegrin \& Normand is really a genus of Santalaceae. Bull. Mus. Nat. d'Hist. Nat., 4e série. Section B, Adan. 4. 355-363.

Hardie, A. D. K. (1963). Okoubaka - a rare juju tree. The Nig. Field, 27(2), 70-72.

Hawthorne, W. D. (1995). Ecological profiles of Ghanaian forest trees. Tropical Forest Papers 29. OFI/ODA, Oxford. 345 pp.

Hockings, K. J. (2007). Human-chimpanzee coexistence at Bossou, the Republic of Guinea: A chimpanzee perspective. A thesis submitted for the degree of Doctor of Philosophy at Department of Psychology, University of Stirling. 272 pp.

Houghton, P. J. (2003). Herbal Practitioners and Pharmacists in Ghana. The Pharm. J. 271, 93-94.

Hutchinson, J., \& J. M. Dalziel (1958). Flora of West Tropical Africa, (Second edition), (ed. 
Keay, R.W.J), Volume 1, Parts 1 \& 2. Crown Agents for Oversea Governments and Administrations, London UK. 828 pp.

Idu, M., \& Onyibe, H. I. (2007). Medicinal plants of Edo State, Nigeria. Res. J. Med. Plants, $1(2), 32-41$.

Ihenyen, J., Okoegwale, E. E., \& Mensah, J. K. (2009). Composition of Tree Species in Ehor Forest Reserve, Edo State, Nigeria. Nat. Sci. 7(8), 8-18.

Ihenyen, J., Mensah, J. K, \& Okoegwale, E. E. (2010). Tree/shrubs species diversity of Ehor Forest Reserve in Uhunmwode Local Government Area of Edo State, Nigeria. Researcher, 2(2). $37-49$.

Ihenyen, J., J. K Mensah, W. O Osunde, and E. Ogie-Odia (2011). Checklist of the Tree/Shrub Species of Edo State, Nigeria. J. Appl. Env. Biol. Sci. 1(9), 276-282.

Irvine, F. R. (1961). Woody Plants of Ghana. London, Oxford University Press. 868 pp.

Isichei, A. O. (2010). Endangered Plants in Nigeria: Time for a new paradigm for vegetation conservation. The Nig. Field, 75, 64-84.

Isikhuemen, E. M., \& Iduozee, O. F. (2008). Degraded forests in protected landscapes: prospects for biodiversity rehabilitation in Urhonigbe Forest Reserve, Edo State, Nigeria. In: Parrotta, J.A., A. Oteng-Yeboah, \& J. Cobbinah (eds.) Traditional Forest-Related Knowledge and Sustainable Forest Management in Africa. IUFRO World Series, volume 23. 220 pp.

Ita, P. B., \& Offiong, E. E. (2013). Medicinal Plants Used in Traditional Medicine by Rural Communities in Cross River State, Nigeria. J. Health, Med. Nurs. 1. 23-29.

IUCN (International Union for the Conservation of Nature) (2001). IUCN Red List Categories and Criteria, Version 3.1. IUCN Species Survival Commission. IUCN, Gland, Switzerland and Cambridge, UK.

Iwu, M. M. (2014). Handbook of African Medicinal Plants (2nd Edition). CRC Press, Boca Raton FL. 506 pp.

Jachmann, H. (2008). Monitoring law-enforcement performance in nine protected areas in Ghana. Biol. Cons. 141, 89-99. http://dx.doi.org/10.1016/j.biocon.2007.09.012

Jones, F.A. \& Muller-Landau, H.C. (2008) Measuring long-distance seed dispersal in complex natural environments: an evaluation and integration of classical and genetic methods. J. Ecol. 96, 642-652. http://dx.doi.org/10.1111/j.1365-2745.2008.01400.x

Kassi, J. N., Kouassi, R. H., \& Yongo, D. O. (2012). Analyse de la flore de la forêt classée de Sanaimbo à Bongouanou - Dimbokro (Côte d'Ivoire). Int. J. Biol. Chem. Sci. 6(5). 2139-2148. http://dx.doi.org/10.4314/ijbcs.v6i5.21

Keay, R.W.J., Onochie, C. F. A., \& Stanfield, D. P. (1964). Nigerian trees. Federal Department of Forest Research. Nigerian National Press, Ibadan. 495 pp.

Keay, R. W. J. (1989). Trees of Nigeria. A revised version of Nigerian trees $(1960,1964)$ by 
RWJ. Keay, CFA Onochie and DP Stanfield. Clarendon Press, Oxford, United Kingdom. 476.

Kitin, P., Beeckman, H., Fujii, T., Funada, R., Noshiro, S., \& Abe, H. (2009). What is disjunctive xylem parenchyma? A case study of the African tropical hardwood Okoubaka aubrevillei (Santalaceae). Am. J. Bot. 96(8). 1399-1408. http://dx.doi.org/10.3732/ajb.0800355

Kohlrausch, S. (2011). Okoubaka aubrevillei a secret and unknown jewel in veterinary homeopathy. British Association of Homeopathic Veterinary Surgeons Summer 2011 issue, pp $7-8$.

Kone, M., Vangah-Mandah, O. M., Kouakou, H., Yapo, A. P., Bleyere, N. M., Sereme, A., Millogo-Rasolodimby, J., Guinko, S., \& Nacro, M. (2008). Proprietes therapeutiques des plantes a tanins du Burkina Faso. Pharma. Méd. Trad. Afr. 15. 41-49

Kuijt, J. (1969). The biology of parasitic flowering plants. Berkeley: University of California Press. 246 pp.

Kyereh, B., Swaine, M. D., \& Thompson, J. (1999). Effect of light on the germination of forest trees in Ghana. J. Ecol. 87. 772-783. http://dx.doi.org/10.1046/j.1365-2745.1999.00386.x

Ladipo, D. O., Adebisi, A. A., \& Bosch, C. H. (2008). Okoubaka aubrevillei Pellegr. \& Normand. In: Schmelzer, G.H. and A. Gurib-Fakim (Eds.). Prota 11(1): Medicinal plants/Plantes médicinales 1. [CD-Rom]. PROTA, Wageningen, Netherlands.

Lebacq, L. \& Dechamps, R. (1964). Essais d'identification anatomigue des bois d' Afrique centrale. Annales Musée royal de l' Afrique centrale, série IN-8, Sciences economiques, no. 3. Royal Museum for Central Africa, Tervuren, Belgium.

Lebacq, L., \& Dechamps, R. (1967). Contribution a un inventaire de forets du Nord-Kasai. Annales Musée royal de l' Afrique centrale, série IN-8, Sciences economiques, no. 5. Royal Museum for Central Africa, Tervuren, Belgium.

Lemée, A. M. V. (1959). Dictionnaire descriptif et synonymique des genres de plantes phanérogames, tome 10, $220 \mathrm{pp}$.

Léonard, J. (1947). Notulae Systematicae I. (Moraceae, Opiliaceae, Olacaceae, Octoknemaceae que africanae). Bull. Jar. Bot. l'État Brux. 18, 145-153.

Léonard, J., \& G. Troupin (1950). Observations sur le genre Okoubaka Pellegrin \& Normand (Octoknemaceae). Bull. Jar. Bot. l'État Brux. 20(1), 11-14.

Louis, J. (1948). Octoknemaceae. In: Robyns, W., P. Staner, E. De Wildeman, R. Germain, G. Gilbert, L. Hauman, M. Homès, J. Lebrun, J. Louis, M. Vanden Abeele, and R. Boutique (eds.) Flore du Congo Belge et du Ruanda-Urundi. Spermatophytes. Volume 1. Institut National pour l'Étude Agronomique du Congo belge, Brussels, Belgium. 446 pp.

Lowe, J. (2012). Comment on the research note Igi-nla (big tree). The Nig. Field 77, 127-128

Lucas, G. L. (1968). Olacaceae. In: MILNE-REDHEAD, E. and POLHILL, R.M. (eds.) Flora of Tropical East Africa. Crown Agents for Oversea Governments and Administrations, London. 


\section{MInstitute ${ }^{\text {Much }}$}

$15 \mathrm{pp}$.

Maercklein, D. (2008). 118/119 Biodiversity and Tropical Forest Assessment for Niger. USDA Forest Service/International Forestry for USAID/Bureau for Africa. Washington, DC. 46 pp.

Mafimisebi, T. E., \& Oguntade, A. E. (2010). Preparation and use of plant medicines for farmers' health in Southwest Nigeria: sociocultural, magico-religious and economic aspects. $J$. Ethnobiol. Ethnomed. 6, 1. http://dx.doi.org/10.1186/1746-4269-6-1

Malécot, V. (2002). Histoire, classification et phylogénie des Olacaceae R. Brown (Santalales). $\mathrm{PhD}$ Thesis, Université Pierre et Marie Curie - Paris VI, Paris.

Mangenot, S., \& G. Mangenot (1962). Enquête sur les nombres chromosomiques dans une collection d'espèces tropicales. Bull. Soc. Bot. France, 109 (Sup. 2). 411-447.

Marshall, C. A. M. (2011). Assessing the Impact of Mining Operations on the Vegetation of Liberia from a Global and Local Perspective. Thesis Submitted in partial fulfillment of the requirements for the degree of Master of Arts in the Program in Environmental Studies at Brown University, Providence, Rhode Island. 159pp.

Marshall, C. A., \& Hawthorne, W. D. (2012a). Regeneration Ecology of the Useful Flora of the Putu Range Rainforest, Liberia. Econ. Bot. 66(4). 398-412. http://dx.doi.org/10.1007/s12231-012-9217-0

Marshall, C. A., \& Hawthorne, W. D. (2012b). Important plants of northern Nimba County, Liberia: A Guide to Most Useful, Rare or Ecologically Important Species, with Mano Names and Uses. Oxford Forestry Institute, Oxford, England. 460 pp.

Maundu, P., Kariuki, P., \& Eyog-Matig, O. (2006). Threats to Medicinal Plant Species - an African Perspective. In: Miththapala, S. (ed.) Conserving Medicinal Species: securing a healthy future. IUCN: Ecosystems and Livelihoods Group, Asia 184 pp.

Meduna, A. J., Ogunjinmi, A. A., \& Onadeko, S. A. (2009). Biodiversity Conservation Problems and their Implications on Ecotourism in Kainji Lake National Park, Nigeria. J. Sust. Dev. Afr. 10(4), 59-73.

De la Mensbruge, G. (1966). La germination et les plantules des essences arborées de laforêt dense humide de la Côted'Ivoire. C.T.F.T., Nogent-sur-Marne, 389 pp.

Minter, S. (2009). High Street Herbals: The Top 300 Over-The-Counter Herbal Medicinals. $16 \mathrm{pp}$.

Myren, B. (2011). Magic plants in the south of Ghana. Report of Research internship. Biology Leiden University, Belgium. 52 pp.

Nacci, G. (2010). Thousand Plants against Cancer without Chemo-Therapy. Evidence-based Medicine. 2,050 official scientific publications 2,100 various bibliographical references. $641 \mathrm{pp}$.

NACGRAB (National Centre for Genetic Resources and Biotechnology) (2004). Preliminary 
investigations into vegetative multiplication of some forest trees of phytomedicinal importance in South-West Nigeria. In: Annual Report of the National Centre for Genetic Resources and Biotechnology. Ibadan, Nigeria. 85 pp.

Nagaveni, H. C., \& Anantha Padmanabha H. S. (1986). Seed polymorphism and germination in Santalum album. Van-Vigyan 24, 25-28.

Neuwinger, H. D. (2000). African traditional medicine - a dictionary of plant use and applications. Medpharm Scientific Publishers, Stuttgart. 589 pp.

Neuwinger, H. D. (2004). Plants used for poison fishing in tropical Africa. Toxicon, 44, 417-430.

Nickrent, Daniel L. (1997). The parasitic plant connection, http://www.parasiticplants.siu.edu/

Nickrent, D. L., \& Duff, R. J. (1996). Molecular studies of parasitic plants using ribosomal RNA. In: pp. 28-52

Moreno, M. T., J. I. Cubero, D. Berner, D. Joel, L. J. Musselman, \& C. Parker (eds.) Advances in parasitic plant research, Junta de Andalucia, Direcion General de Investigacion Agraria, Cordoba, Spain.

Nickrent, D. L., Vidal-Russell, R., \& Der, J. P. (2010). A revised classification of Santalales. Taxon, 59, 538-558.

Nickrent, D. L., \& Malécot, V. (2001). A molecular phylogeny of Santalales. In: Fer, A., P. Thalouarn, D. M. Joel, L. J. Musselman, C. Parker, and J. A. C. Verkleij (eds.) Proceedings of the 7th International parasitic weed symposium, Faculte des sciences de Nantes, France. 69-74pp.

Normand, D. (1944). Note sur l' anatomie du bois du genre nouveau Okoubaka. Bull. Soc. Bot. France, 91, 20-25.

Normand, D. (1950). Atlas des bois de la Côte d'Ivoire. Plates 1 - 56 (Octoknema, Okoubaka). Centre Technique Forestier Tropical, Nogent-sur-Marne, France. 146pp.

Normand, D. (1972). Manuel d'Identification des bois commerciaux. Vol. 1. Centre Technique Forestier Tropical, Nogent-sur-Marne, France.

Normand, D., \& J. Paquis (1977). Manuel d'Identification des bois commerciaux. Vol. 2 (Afrique guineo-congolaise). Centre Technique Forestier Tropical, Nogent-sur-Marne, France.

Ogunkunle, A. T. J, Oyelakin, T. M., Enitan, A. O., \& Oyewole, F. E. (2014). A Quantitative Documentation of the Composition of Two Powdered Herbal Formulations (Antimalarial and Haematinic) using Ethnomedicinal Information from Ogbomoso, Nigeria. Evidence-Based Compl. Alt. Med. Volume 2014, Article ID 751291, 8. http://dx.doi.org/10.1155/2014/751291

Okyeman Environment Foundation (2003). Ghana: Community-based Integrated Natural Resources Management Project in Okyeman. Medium-sized project brief (GEF)-29870. Okyeman Foundation, Accra, Ghana. 41pp. 


\section{Macrothink}

Journal of Biology and Life Science ISSN 2157-6076 2015, Vol. 6, No. 1

Oliver-Bever, B. (1986). Medicinal Plants in Tropical West Africa. Cambridge University Press, Cambridge, England. 375.

Osemeobo, G. J. (2005). Living on the Forests: Women and Household Security in Nigeria.

Small-scale For. Econ., Mgt. Policy, 4(3), 343-358. http://dx.doi.org/10.1007/s11842-005-0021-x

Osemeobo, G. J. (2007). Who decides on access to genetic resources? Towards implementation of the convention on biological diversity in Nigeria. Small-scale For. 6. 93-109. http://dx.doi.org/10.1007/s11842-007-9000-8

Oseni, J. O. (2007). Ensuring Peaceful Coexistence between Man and Animal in Protected Areas in Nigeria. Available at: http://peaceparks2007.whsites.net/papers/oseni_peaceful

Owusu-Sekyere, E. H. (2008). Traditional Knowledge on tree characteristics and uses for agroforestry in Ghana. In: Parrotta, J.A., A. Oteng-Yeboah, and J. Cobbinah (eds.) Traditional Forest-Related Knowledge and Sustainable Forest Management in Africa. IUFRO World Series, volume 23, $220 \mathrm{pp}$.

Pellegrin, F., \& Normand, D. (1946). Une nouvelle localité africaine du genre Okoubaka. Bull. Soc. Bot. France, 93, 138-139.

Pierre, J. B. L. (1897). Sur quelques Olacacées du Gabon. Bull. Mens.. Soc. Linn. Paris, 2, $1290-1296$.

Poorter, L., Bongers, F., Kouamý, F. N., \& Hawthorne, W. D (eds.) (2004). Biodiversity of West African Forests: An Ecological Atlas of Woody Plant Species. CAB International, Oxon UK, 528pp.

Rao, L. N. (1942). Parasitism in the Santalaceae. Ann. Bot. 6, 131-149.

Roberts, E. H. (1973). Predicting the storage life of seeds. Seed Sci. Tech. 1. 499-514.

Van Rompaey, R. S. A. R. (1993). Forest gradients in West Africa: a spatial gradient analysis. Doctoral thesis, Wageningen Agricultural University, The Netherlands. 142 pp.

Savill, P. S., \& J. E. D. Fox (1967). Trees of Sierra Leone. Forest Department, Freetown, Sierra Leone. 316pp.

Stauffer, H. U. (1957). Zur Stellung der gattung Okoubaka Pellegrin et Normand. Ber. Schw. Bot. Ges. 67, 422-427.

Struhsaker, T. T., Struhsaker, P. J., \& Siex, S. K. (2005). Conserving Africa's rain forests: problems in protected areas and possible solutions. Biol. Cons. 123, 45-54. http://dx.doi.org/10.1016/j.biocon.2004.10.007

Swaine, M. D., \& Hall, J. B. (1986). Forest structure and dynamics. In: Lawson, G.W. (ed.) Plant Ecology in West Africa. John Wiley \& Sons, Chichester. 376 pp.

Tailfer, Y. (1989). La Forêt dense d'Afrique Centrale: Identification pratique des principaux arbres. Vol. 2. Agence de Coopération Culturelle et Technique (CTA), Paris, France. 


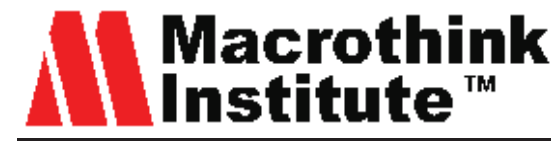

Journal of Biology and Life Science ISSN 2157-6076 2015, Vol. 6, No. 1

Tropicos (2014). Tropicos database. Missouri Botanical Garden. http://www.tropicos.org Accessed August, 27, 2014.

Teut, M., J. Dahler, U. Hirschberg, R. Luedtke, H. Albrecht, \& C. M. Witt (2013). Homeopathic drug proving of Okoubaka aubrevillei: a randomised placebo-controlled trial. Trials, 14, 96. http://dx.doi.org/10.1186/1745-6215-14-96

URS (2013). Nimba Western Area Iron Ore Concentrator Mining Project, Liberia. Environmental and Social Impact Assessment. Volume 4, Part 1.1: Forest Botanical Baseline and Impact Assessment. Prepared for ArcelorMittal Liberia Limited, Monrovia, Liberia. $514 \mathrm{pp}$.

Veenendaal, E. M., Abebrese, I. K., Walsh, M. F., \& Swaine, M. D. (1996a). Root hemiparasitism in a West African rainforest tree Okoubaka aubrevillei (Santalaceae). New Phytol. 134, 487-493. http://dx.doi.org/10.1111/j.1469-8137.1996.tb04366.x

Veenendaal, E. M., Swaine, M. D., Agyeman, V. K., Blay, D., Abebrese, I. K., \& Mullins C. E. (1996b). Differences in Plant and Soil Water Relations in and around a Forest Gap in West Africa during the Dry Season may Influence Seedling Establishment and Survival. J. Ecol. 84(1), 83-90. http://dx.doi.org/10.2307/2261702

Villiers, J-F. (1973). Octoknemaceae. Flore du Cameroun. Volume 15. Muséum National d'Histoire Naturelle, Paris, France. 12 pp.

Voorhoeve, A. G. (1965). Liberian high forest trees. A systematic botanical study of the 75 most important or frequent high forest trees, with reference to numerous related species. 416pp.

Wagner, H., B. Kreutzkamp, \& K. Jurcic (1985). Inhaltstoffe und Pharmakologie der Okoubaka aubrevillei-Rinde. Planta Medica, 51, 404-407. http://dx.doi.org/10.1055/s-2007-969532

Weladji, R. B., \& M. N. Tchamba (2003). Conflict between people and protected areas within the Bénoué Wildlife Conservation Area, North Cameroon. Oryx, 37(1), 72-79. http://dx.doi.org/10.1017/S0030605303000140

Whitmore, T. C. (1978). Gaps in the forest canopy. In: Tomlinson, P.B. and M.H. Zimmermann (eds.) Tropical trees as living systems. Cambridge University Press, New York. 675 pp.

Wright, S. J. (2002). Plant diversity in tropical forests: a review of mechanisms of species coexistence. Oecologia, 130, 1-14. http://dx.doi.org/10.1007/S004420100809

\section{Copyright Disclaimer}

Copyright for this article is retained by the author(s), with first publication rights granted to the journal.

This is an open-access article distributed under the terms and conditions of the Creative Commons Attribution license (http://creativecommons.org/licenses/by/3.0/). 